\title{
Management of chestnut plantations for a multifunctional land use under Mediterranean conditions: effects on productivity and sustainability
}

\author{
A. Martins • G. Marques $\cdot$ O. Borges • \\ E. Portela $\cdot$ J. Lousada $\cdot$ F. Raimundo $\cdot$ \\ M. Madeira
}

Received: 1 February 2010/Accepted: 5 October 2010/Published online: 20 October 2010

(C) Springer Science+Business Media B.V. 2010

\begin{abstract}
Chestnut plantations for fruit production in Northern Portugal have been subjected to intensive management system, including soil tillage, mineral fertilization and pruning. Some of these practices have no positive effect on productivity and soilplant-water relations. Other systems (e.g., no tillage with maintenance of grass cover) have been adopted, aiming a multifunctional land use, exploiting nuts, pasture and edible mushrooms. Thus, an experimental trial was installed to assess the effects of such systems on productivity, sustainability and annual net income, as compared with the conventional system, over a six-year period. The treatments were: conventional soil tillage (CT); no tillage with permanent spontaneous herbaceous vegetation cover $(\mathrm{NV})$; no tillage with permanent rainfed seeded pasture cover (NP); and as NP but with irrigation (NIP). Production of nuts, forage and edible mushrooms were measured
\end{abstract}

A. Martins $(\bowtie) \cdot$ G. Marques · E. Portela .

J. Lousada $\cdot$ F. Raimundo

Universidade de Trás-os-Montes e Alto Douro-CITAB,

Apart. 1013, 5001-801 Vila Real, Portugal

e-mail: amartins@utad.pt

O. Borges

Direcção Regional de Agricultura do Norte (DRAPN)

Delegação do Nordeste Transmontano, Av. General

Humberto Delgado, 5301-903 Bragança, Portugal

M. Madeira

Instituto Superior de Agronomia, Universidade Técnica

de Lisboa, Tapada da Ajuda, 1349-017 Lisbon, Portugal and sustainability was assessed by production and diversity of fungal sporocarps. Annual net income was estimated by the difference between the annual gross outputs (market values for nuts, forage and edible commercial mushrooms) and the annual input costs. The greatest nut and edible mushroom production and sporocarp biodiversity were achieved in the NIP and NV and the smallest in the CT treatment. The highest annual gross output was estimated for the NV and NIP treatments, whereas the highest annual net income was obtained for the NV. No tillage with maintenance of spontaneous grass cover showed to be the most favourable management system, as it has increased productivity and biodiversity.

Keywords Agroforestry systems - Biodiversity . Castanea sativa $\cdot$ Economics $\cdot$ Edible mushrooms . Silvopastoral systems $\cdot$ Soil management
Abbreviations
CT Conventional tillage
D Fruit diameter in frontal view
d Fruit diameter in lateral view
DM Dry matter
FU Feed units
FW Fresh weight
h Fruit height
NV No tillage with herbaceous spontaneous vegetation cover
NP No tillage with rainfed seeded pasture
NIP No tillage with irrigated seeded pasture 


\section{Introduction}

Chestnut plantations for fruit production are an important agroecosystem in Northern Portugal, occupying near $25,000 \mathrm{ha}$, producing $28,000 \mathrm{Mg}$ of fruit ( $84 \%$ of the total national nut production) (INE 2005) which represents an essential source of income for rural areas. Several studies have been carried out to assess the effect of different soil management systems on tree water relations and physiologic response, productivity and pathology (Abreu et al. 1993; Martins and Abreu 1997; Portela et al. 1999; Marcelino et al. 2000; Raimundo 2003; Martins et al. 2005). No advantages of conventional system (soil tillage trice a year) were then observed on fruit production and water saving, as compared with the no tillage with maintenance of herbaceous vegetation cover. Also, negative impacts of conventional tillage have been detected such as decrease of soil organic matter content, increasing risks of soil compaction, soil erosion, and nutrient losses and damage of tree roots, which enhance the occurrence of ink disease induced by Phytophthora cinnamomi (Hogue and Neilsen 1987; Glenn and Welker 1989; Lipecki and Berbeć 1997; Martins et al. 1999; Portela et al. 1999; Marcelino et al. 2000). These effects have been considered as responsible for the decline of chestnut plantations (Abreu et al. 1993; Martins and Abreu 1997; Portela et al. 1999).

Some studies showed that conventional tillage is more deleterious to chestnut orchards under conditions of severe drought, as compared with the maintenance of natural vegetation cover (Raimundo 2003). The tillage system with maintenance of herbaceous vegetation has been reported as a favourable management system to assure productive sustainability and soil quality in Mediterranean agroecosystems such as vineyards (Morlat and Jacquet 2003; Celette et al. 2005) and olive orchards (Hernández et al. 2005; Ramos et al. 2010).

These trends encouraged new strategies of soil management within a multifunctional prospect land use system, taking into account the advantages of grass cover, e.g., increased organic matter, biodiversity and soil permeability and reduced soil erosion hazard (Celette et al. 2005). Silvoarable and silvopastoral systems have been identified as the potential for biological species richness and protection against erosion, reducing agrochemical inputs and increasing the overall resource-use efficiency of the system (Vandmermeer 1989; Jose et al. 2004; Eichhorn et al. 2006). Such systems provide both market (food, wood products, and fodder) and nonmarket goods and services (soil conservation, water and air quality improvement, biodiversity and scenic beauty), contributing to the rural economy and environmental protection (Alavalapati et al. 2004).

System sustainability maintenance is associated with soil quality and biological activity is recognized as a soil quality indicator, given its close relation to water and nutrient availability, soil aeration, biomass production, and it's exceptionally sensitivity to changes in soil conditions (Doran and Zeiss 2000). Therefore, microbial diversity and functional groups of soil fauna are included as indicators for soil quality monitoring (Nortcliff 2002; Schloter et al. 2003). Within soil microbial communities, beneficial saprotrophic and mycorrhizal fungi are critically important soil biotic components in agroecosystems by the positive effects on plant nutrition (Smith and Read 1997), drought tolerance (Garbaye 2000) and protection against root diseases, such as chestnut ink disease (Branzanti et al. 1999). Environmental and soil conditions are particularly important in the development of fungal mycelial and sporocarps (Wiklund et al. 1995; Martínez de Aragón et al. 2007) as fungal species vary in their response to disturbance (Martín-Pinto et al. 2006). Therefore, fungal sporocarps occurrence, mainly ectomycorrhizal fungi, have been used as indicator of soil conditions or disturbance effects on below-ground ecosystems (Termorshuizen and Schaffers 1991; Luoma et al. 2004).

Differences on fungal communities between conventional and no-tillage systems were reported, being no-tillage systems generally more favorable to soil fungi (Beare et al. 1997; Frey et al. 1999). Management practices which promote the beneficial roles of the soil fungi will be essential for sustaining the productivity and ecological integrity of the chestnut orchards. Furthermore, some fungal species produces edible sporocarps, highly prized and only gathered in the wild, which have become an important income on rural areas (Arnolds 1995; Boa 2004). The most valuable and appreciated wild mushrooms in Portugal belongs to the group Boletus edulis s.l., comprising the species Boletus edulis Bull.: Fr., Boletus aestivalis Fr., Boletus aereus Bull.: Fr., and Boletus 
pinophilus Pilát et Dermek. These species are ectomycorrhizal symbionts of chestnut trees and abundant in Mediterranean regions, with a great potential for management (Salerni and Perini 2004).

In this context, chestnut producers are motivated to change the conventional cropping system by the no-tillage system and maintain both rainfed and irrigated grass covers within a multifunctional chestnut orchards use, exploiting nuts, pastures and edible mushrooms. Therefore, to formulate management guidelines for the sustainability of these systems, a field experiment was developed to evaluate the implications of the different soil management systems on: (i) the production and quality of nuts, forage and edible mushrooms; (ii) sustainability, using mushroom productivity and fungal diversity as a soil quality bioindicator; and (iii) annual net income. Results from 2003 to 2008 are reported and discussed.

\section{Materials and methods}

Site description

The study was carried out by an experimental trial established in a private estate, in October 2001, in Northeast Portugal, municipality of Macedo de Cavaleiros $\left(41^{\circ} 35^{\prime} 47^{\prime \prime} \mathrm{N}\right.$ and $6^{\circ} 57^{\prime} 44^{\prime \prime} \mathrm{W}, \quad 700 \mathrm{~m}$ altitude).

The climate is of Mediterranean type with cool and wet winters and warm dry summers. Considering the available climatic data for the meteorological station

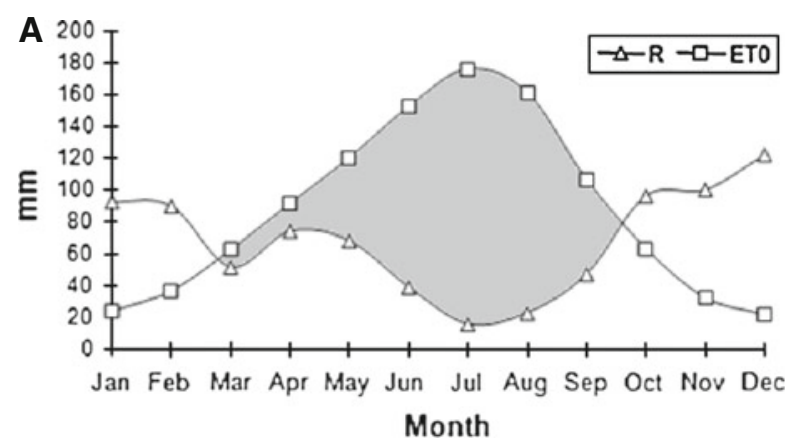

Fig. 1 Rainfall data for the region of the experimental area: a monthly average values for rainfall (R) and reference evapotranspiration (ET0), gray colour area representing the at Bragança (30 km far from the experimental site), for the period 1970-2000, the mean annual rainfall was $818 \mathrm{~mm}$, mainly concentrated $(85 \%)$ from October to May (Fig. 1). The monthly distribution of rainfall and reference evapotranspiration, according to Hargreaves (1975), is shown in the Fig. 1a, which illustrates the climatic water deficit in the experimental area during the summer period. The mean annual temperature was $11.9^{\circ} \mathrm{C}$ (INMG 1991), and monthly mean air temperature ranged from $3.4^{\circ} \mathrm{C}$ in winter (December) to $22.4^{\circ} \mathrm{C}$ in summer (August).

During the study period, temperature was within the pattern of the reference period (1970-2000). The mean annual rainfall values for the study years and for the reference period 1970-2000, considering for each year the growing season (November to October), are also represented in Fig. 1b. As illustrated there was a high interannual fluctuation on total annual rainfall, being 2005 and 2008 the years with the lowest values and 2003 with the highest one. Also it was observed a high heterogeneity among years in rainfall distribution over the year (Fig. 2a, b).

The landscape of the study area is gently undulating with slopes varying from 0 to $4 \%$, and geology made up schists (Siluric formation). The soils are mostly classified as Dystric Regosols (FAO 2006), sandy loam to loam, $\mathrm{pH}$ value in the upper horizon (Ap) ranging from 4.5 to 5.4, low contents of organic $\mathrm{C}$ and exchangeable base cations and high contents of extractable $\mathrm{P}$ and $\mathrm{K}$, due to mineral fertilization. The subsurface horizon ( $\mathrm{C}$ horizon) shows extremely low contents of organic $\mathrm{C}$ and nutrients, and is much more acidic than the Ap horizon (Table 1).

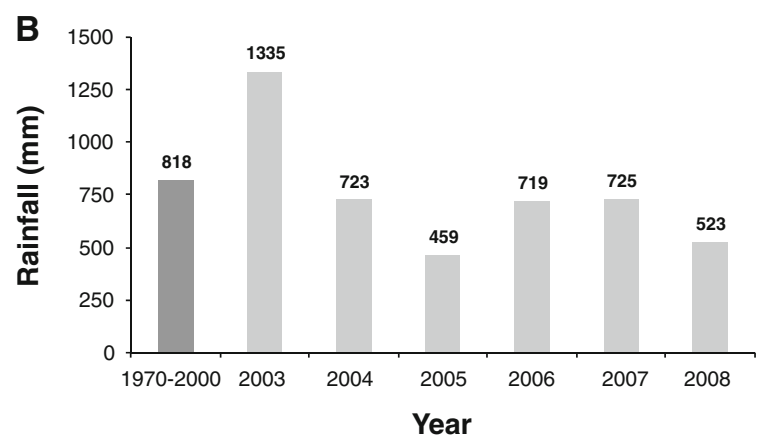

climatic water deficit period; b Mean annual rainfall for the reference period 1970-2000 and for the study years 

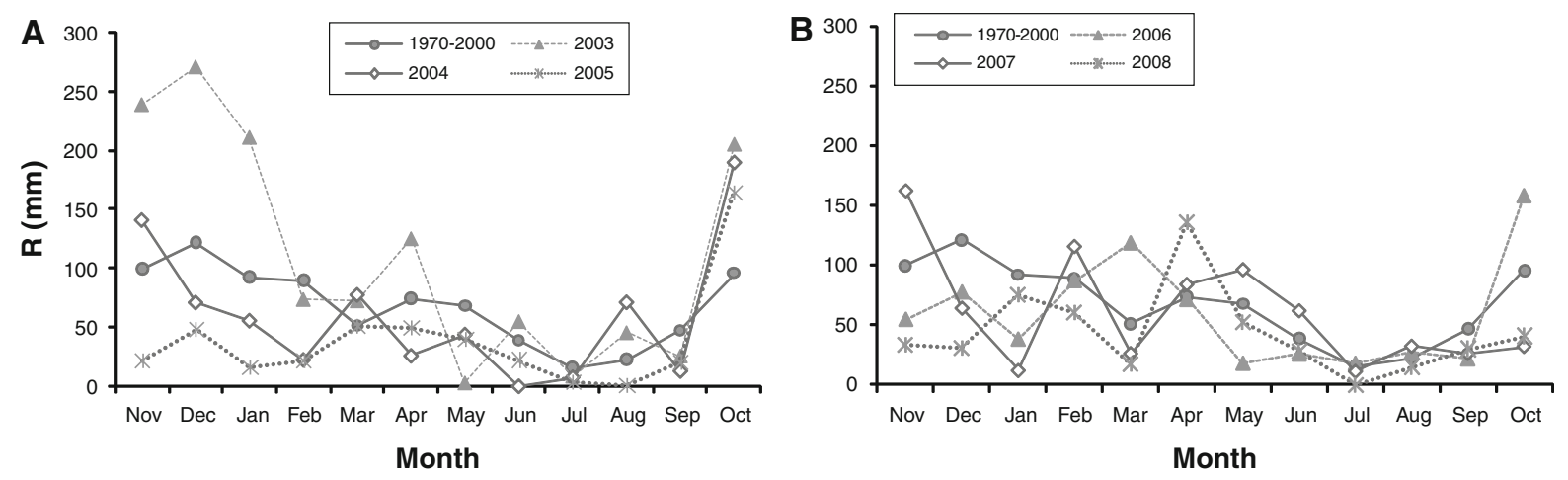

Fig. 2 Monthly average rainfall for the growth reference period (1970-2000), from 2003 to 2005 (a) and 2006 to 2008 (b)

Experimental layout

In October 2001, an experimental system was installed in a 40 year old stand of Castanea sativa Miller (Longal cultivar) at $12 \times 12 \mathrm{~m}^{2}$ spacing. Average trunk diameter at breast height, crown projected area and height of trees were $39.8 \mathrm{~cm}$, $86.0 \mathrm{~m}^{2}$ and $9.9 \mathrm{~m}$, respectively. Percentage of area beneath tree crowns was $72.4 \%$ and in the open $27.6 \%$. The experimental design consisted of four treatments: (a) Conventional soil tillage (reference or control) down to $15-20 \mathrm{~cm}$ depth with a tine cultivator thrice a year, that is, after fruit harvesting and litter fall to incorporate organic residues into the soil, in late winter to incorporate fertilizers, and in late spring for soil surface crust destruction and control weeds (CT); (b) No tillage and maintenance of soil surface with spontaneous herbaceous vegetation (NV); (c) No tillage and maintenance of soil surface with rainfed seeded pasture $(25 \mathrm{~kg}$ seed/ha) (NP); and (d) as NP but with irrigation (NIP). Each treatment (replicated three times) was installed in plots randomly distributed in the experimental area, each one with $600 \mathrm{~m}^{2}$ and six trees. At the beginning of the experiment the following fertilizers were applied in all the treatments: $5,000 \mathrm{~kg}$ of limestone $\left(80 \% \mathrm{CaCO}_{3} ; 19 \% \mathrm{MgCO}_{3}\right), 1,000 \mathrm{~kg}$ of superphosphate $(18 \%), 500 \mathrm{~kg}$ of $\mathrm{KCl}(60 \%)$ and $10,000 \mathrm{~kg}$ of organic fertilizer $(50 \%$ of moisture, $69 \%$ organic matter; $1.5 \% \mathrm{~N} ; 1.5 \% \mathrm{P}_{2} \mathrm{O}_{5}, 0.25 \% \mathrm{~K}_{2} \mathrm{O} ; 1.7 \% \mathrm{CaO}$; $0.3 \% \mathrm{MgO}$ ). Irrigation (two sprinklers) was applied to three trees per plot, that is, nine irrigated trees were considered in NIP treatment. The irrigation schedule and volumes were according Table 2.
In 2003, 2004 and 2005, dates and irrigation volumes were adopted according to the schedule of irrigation followed by the land owner, taking into account the rainfall and temperature during the summer period. For 2006-2008, irrigation was applied when a minimum value of $-0.6 \mathrm{MPa}$ for predawn leaf water potential was achieved, which was observed as a limit value for favourable vegetative conditions to the study species (Martins et al. 2005) and balancing the reference evapotranspiration (Hargreaves 1975) for the experimental area conditions.

In NP and NIP treatment plots, the pasture (a mixture of Dactilis glomerata L., Lolium multiflorum Lam., Trifolium subterraneum L., T. repens L., and $T$. pratense L.) was seeded in October 2001, using $25 \mathrm{~kg} \mathrm{ha}^{-1}$ of the mixture, covered by chisel, after spreading the seeds. In the NV treatment spontaneous herbaceous vegetation was mainly composed by Chamaemelum mixtum (L.) All., Ornithopus compressus L., Rumex acetosella L. subp. angiocarpus (Murb.) Murb. and Vulpia bromoides (L.) S.F. Gray. The vegetation in NV, NP, and NIP treatments covered about $100 \%$ of the soil surface and was grazed by sheep herds.

\section{Data collection}

Nut production was quantified from 2003 to 2006, through the amount of fruits collected in three trees per plot (nine trees per treatment). To estimate the production, 70 trees per ha were taken into account, with $12 \times 12 \mathrm{~m}^{2}$ spacing. Nut quality was assessed by the fruit weight $\left(\mathrm{g}\right.$ fruit $^{-1}$ ) and a size index 
Table 2 Dates of first and last irrigation, number of irrigations and water volume per year

\begin{tabular}{lllll}
\hline Year & First irrig & Last irrig & Number & $\begin{array}{l}\text { Water } \\
\text { volume }(\mathrm{mm})\end{array}$ \\
\hline 2003 & Jun 09 & Sep 26 & 14 & 217 \\
2004 & Jun 15 & Sep 21 & 8 & 78 \\
2005 & Jun 30 & Oct 01 & 10 & 220 \\
2006 & Aug 01 & Sep 20 & 7 & 70 \\
2007 & Jul 31 & Sep 21 & 5 & 83 \\
2008 & Aug 25 & Oct 06 & 6 & 77 \\
\hline
\end{tabular}

$[(\mathrm{D}+\mathrm{d}+\mathrm{h}) / 3, \mathrm{~mm}]$, where $D$ is the fruit diameter in frontal view, $d$ is the fruit diameter in lateral view and $h$ is the fruit height (Botu et al. 1999). Both parameters were also measured from 2003 to 2006, and for fruit weight and size, 180-270 fruits and 64-90 fruits, respectively, were used per treatment per year.

Forage production was measured (2006-2008) by weighting the dry matter in a frame of $0.5 \mathrm{~m}^{2}$, with three replicates by plot both beneath canopy and open areas, nine replications per treatment, three times a year (beginning spring, middle June, and late autumn). Average forage and mushroom production by hectare was estimated taking into account the percentage of area out and under tree crowns.

Mushroom productivity and diversity were assessed through sporocarps surveys, from 2006 to 2008. Sporocarps were collected weekly, during the spring (May-July) and autumn (September-November) fruiting seasons (15 samplings per year), under tree crown of three trees per plot (nine trees per treatment), focusing on sampling units that are more likely to be important in obtaining a precise estimate of the productivity (Lund 1998). In 2006, sporocarps were also collected in the open and the respective percentage (20\%) regarding the production under tree crown was then used in the subsequent years to estimate the total production by ha, considering an open area of $27.6 \%$ of the total. Clumps of sporocarps were considered as a single occurrence and hypogeous sporocarps or fructifications in woody debris were not taken into account. Specimens were identified to species level in most cases and samples that could not be identified at the species level were grouped into a genus taxon. For economic evaluation, sporocarps were categorized according edibility and commercial importance. 
Economic evaluation

The annual net income was estimated by the difference between the annual gross outputs and the input costs per treatment. The annual gross outputs was estimated by the production and market value of nuts $\left(\mathrm{kg} \mathrm{FW} \mathrm{ha}^{-1}\right)$, forage ( $\mathrm{kg} \mathrm{FU} \mathrm{ha}{ }^{-1}$, being $\left.1 \mathrm{FU}=0.75 \mathrm{~kg} \mathrm{DM}\right)$ and edible commercial mushrooms $\left(\mathrm{kg} \mathrm{FW} \mathrm{ha}^{-1}\right)$. The market price for nuts was estimated considering the number of nuts per $\mathrm{kg}$ of fresh weight, a standard parameter used to establish their market price. Annual input costs were estimated by the costs associated with each treatment: tillage, seeding, soil fertilization, pruning, irrigation, fruit and edible mushrooms harvests. Irrigation costs included the substructures (well drilling, pumps, pipes, and sprinklers) at local market prices (considering 30 years of useful life) water, yearly running energy, equipment conservation and manpower.

\section{Statistical analysis}

For nut, forage, mushroom production, fungal species richness and sporocarp occurrence, the analysis of variance ANOVA was followed, considering as source of variation the year and treatment effect and the position related to tree canopies (in case of forage production), its interaction and the error effect (site and trees by treatment and year), with the correspondent post hoc test for year and treatment effects. In both cases it was used the JMP (SAS, Institute Inc.) software and for the post hoc the Tukey HSD multiple comparison test (for a significance level $P<0.05$ ).

Fungal species diversity in the different treatments was estimated using the total number of species or richness $(\mathrm{S})$, the Shannon index $\left(\mathrm{H}^{\prime}=\Sigma p_{i} \ln p_{i}\right)$, where $p_{i}$ is the proportion of individuals of the ith species (Krebs 1994). The Shannon index varies from 0 for communities with only a single taxon to high values for communities with many taxa, each with few individuals. For diversity analysis it was used the statistical ecology program PAST 1.79 (Hammer et al. 2001).

\section{Results and discussion}

Nut production and quality

Nut production and quality results are reported in Tables 3 and 4 . The influence of the year as source of variation on nut production was much higher than that of treatments (52.2 and $12.7 \%$, respectively), and a considerable error effect was observed (32.8\%) (Table 3). Regarding nut weight and size index (nut quality), the analysis of variance showed that the effect of years, as sources of variation, was also stronger (28.9 and $26.4 \%$, respectively) than that associated with treatments (10.1 and $11.1 \%$, respectively). Also, nut quality was affected at low extent (1.9 to $6.1 \%$ ) by the interaction year $\times$ treatment. In addition, a strong error effect on nut quality (55.7-59.0\%) was observed, which can be attributed to the influence of differences on trees and site quality.

Significant differences among treatments and years on nut production (Table 4) were observed. The CT and NP treatments showed the lowest average values (18.8 and $19.6 \mathrm{~kg}$ tree ${ }^{-1}$, respectively) and the highest values were observed in the NV and NIP (27.2 and $24.4 \mathrm{~kg}$ tree ${ }^{-1}$, respectively). The advantage of the no-tillage system with spontaneous herbaceous vegetation when compared with the conventional system may be associated with the fact that the damage of the tree root system is avoided and organic C losses reduced (Raimundo 2003). Comparing treatments with spontaneous herbaceous vegetation (NV) with those with seeded pasture (NP), the significantly low nut production in the latter may be associated with great amounts of herbaceous vegetation (e.g., $3.2 \mathrm{t} \mathrm{ha}^{-1}$ ) (Fig. 3). These results agree with previous findings by Raimundo (2003) in the same region and similar conditions; also, seeded pasture, with leguminous species may be more competitive for water resources than spontaneous species as reported by Dupraz et al. (1998).

No significant effect of irrigation was observed on nut production, which can be interpreted as a consequence of study chestnut plantations are deepwater-dependent (Martins et al. 2005, 2010) and irrigation supply only affected the top soil layer (see Table 2). However, a positive impact of soil water supply on yield and fruit quality has been demonstrated in a wide range of environmental conditions (Ferreres and Evans 2006). For instance, studies developed under Mediterranean conditions, for almond trees (Goldhamer et al. 2006) and apricot trees (Pérez-Pastor et al. 2009), irrigating 55-85\% of the potential seasonal evapotranspiration in the first study and, 25-100\% in the last one, depending the 
Table 3 Analysis of variance related to the effect of years and treatments on nut production, nut quality (fruit weight and size index) and forage production
No significant interactions are not shown

\begin{tabular}{|c|c|c|c|c|c|}
\hline Source of variation & df & Mean square & $F$-value & $P$-value & $\begin{array}{l}\text { Expected } \\
\text { variation }(\%)\end{array}$ \\
\hline \multicolumn{6}{|c|}{ Fruit production $\left(\mathrm{kg} \mathrm{DM}\right.$ tree $\left.^{-1}\right)$} \\
\hline Year (Y) & 3 & 632177.58 & 55.09 & 0.0001 & 52.2 \\
\hline Treatments $(\mathrm{T})$ & 3 & 162967.26 & 14.2 & 0.0001 & 12.7 \\
\hline Error (tree/Y/T) & 120 & 11475.71 & & & 32.8 \\
\hline \multicolumn{6}{|c|}{ Fruit weight $\left(\mathrm{g}\right.$ fruit $\left.^{-1}\right)$} \\
\hline Year $(Y)$ & 3 & 3168.67 & 469.73 & 0.0001 & 28.9 \\
\hline Treatments $(\mathrm{T})$ & 3 & 1111.74 & 164.81 & 0.0001 & 10.1 \\
\hline $\mathrm{Y} \times \mathrm{T}$ & 9 & 58.40 & 8.66 & 0.0001 & 1.9 \\
\hline Error $($ tree/Y/T) & 3816 & 6.75 & & & 59.0 \\
\hline \multicolumn{6}{|c|}{ Fruit size index (mm) } \\
\hline Year (Y) & 3 & 913.41 & 150.71 & 0.0001 & 26.4 \\
\hline Treatments $(\mathrm{T})$ & 3 & 309.84 & 51.12 & 0.0001 & 11.8 \\
\hline $\mathrm{Y} \times \mathrm{T}$ & 9 & 58.70 & 9.69 & 0.0001 & 6.1 \\
\hline Error $($ tree/Y/T) & 936 & 6.06 & & & 55.7 \\
\hline \multicolumn{6}{|c|}{ Forage production (t DW ha ${ }^{-1}$ ) } \\
\hline Year $(Y)$ & 2 & 549680.41 & 63.18 & 0.0001 & 37.9 \\
\hline Treatments $(\mathrm{T})$ & 2 & 212597.19 & 24.44 & 0.0001 & 21.4 \\
\hline Position & 1 & 121129.31 & 13.92 & 0.0003 & 7.9 \\
\hline Error $($ site/Y/T/S $)$ & 96 & 8700.20 & & & 32.9 \\
\hline
\end{tabular}

growing season period, reported a positive effect of deficit irrigation on yield and fruit quality. In our study, the lack of positive response of yield to irrigation may be associated with the high irrigation deficit adopted by the land owners (percentage of irrigation related to the water deficit was $14-46 \%$ ), which was much high regarding that followed in the abovementioned studies.

Regarding weather conditions, significant differences in nut production were observed between 2005 $\left(9.2 \mathrm{~kg}\right.$ tree $\left.^{-1}\right)$ and the other study years $(2003,2004$, and 2006), which ranged from 25.5 to $27.9 \mathrm{~kg}$ tree $^{-1}$. The strong influence of weather conditions on fruit production and quality may be an effect of the annual rainfall amount and distribution. In fact, 2005 was the driest year, and the rainfall from October 2004 to September 2005 was similar to the reference evapotranspiration (Fig. 2), which may affect the replenishment of water retention capacity of deep soil layers.

Effects of treatments on fruit weight and size index followed the trend observed for nut production. The $\mathrm{NV}$ and NIP treatments showed the highest fruit weight (11.1 and $10.8 \mathrm{~g}_{\text {fruit }}^{-1}$, respectively) and size (27.4 and $27.1 \mathrm{~mm}$, respectively), while the CT treatment the lowest values $\left(8.8 \mathrm{~g}_{\text {fruit }}{ }^{-1}\right.$ and $24.9 \mathrm{~mm}$ ). The average number of nuts per $\mathrm{kg}$ was 90, 93, 105, and 114 for NV, NIP, NP, and CT treatments respectively, which was taken into account to estimate their market price. Values of fruit weight and fruit size (Table 4) were lower in 2005 (7.6 g fruit $^{-1}$ and $24.6 \mathrm{~mm}$, respectively) than in the other study years (10.3-11.2 $\mathrm{g} \mathrm{fruit}^{-1}$ and $27.1-27.8 \mathrm{~mm}$, respectively). Therefore, nut quality indexes were also dependent on treatments and the year weather conditions.

\section{Forage production}

As for nut production, the influence of the year as a source of variation was stronger $(37.9 \%)$ than that associated with treatments (21.4\%), while the effect of the position (beneath tree crowns or open areas) was very low (7.9\%); also, a considerable error effect was found $(32.9 \%)$. No effect of the interactions between treatments, years and position was found (Table 3).

Significant differences between years were observed in forage production, with higher value in 2007 (381.1 $\mathrm{g} \mathrm{DM} \mathrm{m}^{-2}$ ) than in 2006 and 2008 
Table 4 Average values for nut production ( $\mathrm{kg} \mathrm{FW} \mathrm{ha}^{-1}$ ), fruit weight ( $\mathrm{g}_{\text {fruit }}{ }^{-1}$ ), and size index $(\mathrm{mm})$, across treatments and years

\begin{tabular}{|c|c|c|c|c|c|}
\hline Treatment & $n$ & Average $\pm \mathrm{SE}$ & Year & $n$ & Average $\pm \mathrm{SE}$ \\
\hline \multicolumn{6}{|c|}{ Nut production $\left(\mathrm{kg} \mathrm{DM}\right.$ tree $\left.^{-1}\right)$} \\
\hline $\mathrm{CT}$ & 34 & $18.8 \pm 2.1 \mathrm{~b}$ & 2003 & 39 & $27.9 \pm 1.6 \mathrm{a}$ \\
\hline NV & 35 & $27.2 \pm 2.1 \mathrm{a}$ & 2004 & 36 & $25.5 \pm 1.7 \mathrm{a}$ \\
\hline NP & 37 & $19.6 \pm 2.0 \mathrm{~b}$ & 2005 & 36 & $9.2 \pm 1.7 \mathrm{~b}$ \\
\hline NIP & 36 & $24.4 \pm 2.1 \mathrm{a}$ & 2006 & 31 & $27.8 \pm 1.8 \mathrm{a}$ \\
\hline \multicolumn{6}{|c|}{ Fruit weight $\left(\mathrm{g}\right.$ fruit $^{-1}$ ) } \\
\hline $\mathrm{CT}$ & 951 & $8.8 \pm 0.10 \mathrm{c}$ & 2003 & 961 & $10.3 \pm 0.10 \mathrm{~b}$ \\
\hline NV & 963 & $11.1 \pm 0.10 \mathrm{a}$ & 2004 & 720 & $11.5 \pm 0.10 \mathrm{a}$ \\
\hline NP & 960 & $9.5 \pm 0.11 \mathrm{~b}$ & 2005 & 1079 & $7.6 \pm 0.09 \mathrm{c}$ \\
\hline NIP & 958 & $10.8 \pm 0.09 \mathrm{a}$ & 2006 & 1072 & $11.2 \pm 0.08 \mathrm{a}$ \\
\hline \multicolumn{6}{|c|}{ Size index $(\mathrm{mm})$} \\
\hline $\mathrm{CT}$ & 237 & $24.9 \pm 0.21 \mathrm{c}$ & 2003 & 336 & $27.1 \pm 0.14 b$ \\
\hline NV & 237 & $27.1 \pm 0.17 \mathrm{a}$ & 2004 & 252 & $27.8 \pm 0.13 \mathrm{a}$ \\
\hline NP & 237 & $26.1 \pm 0.21 \mathrm{~b}$ & 2005 & 360 & $24.6 \pm 0.17 \mathrm{c}$ \\
\hline NIP & 237 & $27.4 \pm 0.16 \mathrm{a}$ & 2006 & 360 & $27.4 \pm 0.16 \mathrm{a}$ \\
\hline
\end{tabular}

Different letters in the same column, for each measurement, means the existence of significative differences between treatments or years $(P<0.05)$
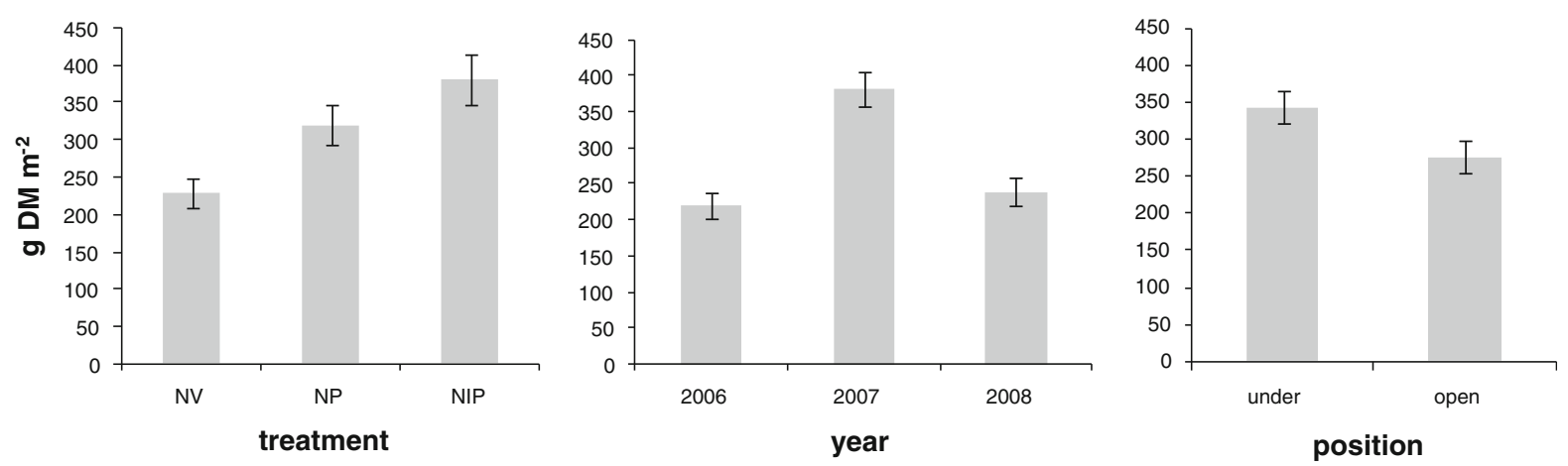

Fig. 3 Forage production $\left(\mathrm{g} \mathrm{DM} \mathrm{m}{ }^{-2}\right)$, according to treatments $(n=36)$, years $(n=54)$ and position $(n=54)$. Bars show SE

(220.4 and $238.5 \mathrm{~g} \mathrm{DM} \mathrm{m}^{-2}$, respectively). Greater forage production in 2007 than in 2006 is not an effect of the annual rainfall amount (725 and $719 \mathrm{~mm}$, respectively). It may be mostly associated with the rainfall amount during spring season; in fact, the rainfall during May and June was greater in 2007 $(158.6 \mathrm{~m})$ than in the other study years (44.0 and $81.0 \mathrm{~mm}$, respectively for 2006 and 2008; see Fig. 1 b). This trend agrees with the greater forage production (7.0 to $8.7 \mathrm{t} \mathrm{DM} \mathrm{ha}^{-1}$ year $^{-1}$ ) reported by RozadosLorenzo et al. (2007) for Castanea sativa plantations (58\% of tree crown cover), in wetter areas with similar mean annual temperature (Galicia, Spain).

Forage production was significantly different among treatments, with the highest value in the NIP treatment and the lowest in the NV (381.0 and $228.3 \mathrm{~g} \mathrm{DM} \mathrm{m}^{-2}$ ), while the NP showed intermediate values (320.1 $\mathrm{g} \mathrm{DM} \mathrm{m}^{-2}$ ). The lower production observed in the NV treatment, as compared with that in the NP, may be associated with the fact that spontaneous species are commonly less productive (Moreira 2007). This trend is in agreement with results of studies regarding productivity of rainfed pastures in the region of the present study (in identical climatic conditions), where the production of improved seeded pastures ranged from 2.8 to $4.2 \mathrm{t}$ $\mathrm{ha}^{-1} \mathrm{y}^{-1}$, while that of spontaneous species ranged from 1.5 to $2.4 \mathrm{t} \mathrm{ha}^{-1} \mathrm{y}^{-1}$ (Moreira and Trindade 1992; Moreira 2007).

Despite of watering in the NIP treatment, differences of forage production between this treatment and the NP (381.0 and $320.1 \mathrm{~g} \mathrm{DM} \mathrm{m}^{-2}$, respectively) were small, which may be ascribed to irrigation schedule. In fact, the first irrigation was 
applied in middle summer (see Table 2), after the second forage sampling (late June) and therefore, during the crucial period for forage production, the NP and NIP treatments were similar regarding water availability.

A significant higher forage production was observed under tree crown than in the open (343.3 and $276.3 \mathrm{~g} \mathrm{DM} \mathrm{m}^{-2}$, respectively) (Fig. 3), following results reported for other Mediterranean agroforestry systems. In fact, a similar trend was reported by Pereira et al. (2002), in the region of the present study, for pastures with spontaneous vegetation with scattered Fraximus angustifolea, which was associated with the increase of soil fertility under tree crowns. Also, Moreno (2008), under stronger Mediterranean conditions, reported the same trend for the silvopastoral system of Iberian "dehesas".

\section{Mushroom productivity}

A higher influence of the treatments as a source of variation than the year (67.7 and $13.4 \%$ respectively) was observed for total sporocarp production (Table 5). Total sporocarp biomass differed significantly among treatments, with the highest value in the NIP and the lowest in the CT treatments (151.4 and $22.5 \mathrm{~kg} \mathrm{FW} \mathrm{ha}^{-1}$, respectively) (Fig. 4). The sporocarp productivity in the CT treatment was only 20 and $28 \%$ of that in the no-tillage system with the maintenance of natural and seeded vegetation cover, respectively.
Productivity of both total and edible-marketed mushrooms (2006-2008) is shown in Fig. 4. For economic analysis, only the most abundant marketable edible mushrooms were considered: Boletus edulis s.l. (B. edulis, B. pinophilus, B. aereus and B. aestivalis), Russula cyanoxantha, Lepista nuda and Boletus fragans. Other species found in the studied orchard are traditionally consumed and marketed but occurred sporadically, such as Macrolepiota procera (Scop.: Fr.) Singer and the highly prized Cantharellus cibarius Fr.

Significant differences were found among years, with the highest value in $2006\left(122.7 \mathrm{~kg} \mathrm{FW} \mathrm{ha}^{-1}\right)$ and lowest and similar in 2007 and 2008 (75.1 and $83.0 \mathrm{~kg} \mathrm{FW} \mathrm{ha}{ }^{-1}$, respectively) (Fig. 4). This might be due to the annual variation in weather conditions, mainly in the amount of rainfall, a crucial factor for the development of the fungal fruiting bodies in the fall season (Martínez de Aragón et al. 2007). Thus, the highest productivity in 2006 can be explained by the higher rainfall than normal in the fall season of 2006 (October and November; Fig. 2b) whereas the fall seasons in 2007 and 2008 were much drier than normal.

In contrast with the total sporocarp production, the year did not show any significant effect as source of variation in the productivity of commercial edible mushrooms, while a strong effect of treatments $(67.5 \%)$ and the residue $(32.5 \%)$ was observed (Table 5). However, longer study periods are necessary to evaluate inter annual weather conditions, to take into account weather variability, since the

Table 5 Analysis of variance related to the effect of years and treatments on total sporocarp biomass and commercial edible mushroom production

\begin{tabular}{|c|c|c|c|c|c|}
\hline Source of variation & df & Mean square & $F$-value & $P$-value & Expected variation $(\%)$ \\
\hline \multicolumn{6}{|l|}{ Total sporocarp biomass } \\
\hline Year $(Y)$ & 2 & 11485.47 & 10.95 & 0.0004 & 13.4 \\
\hline Treatments $(\mathrm{T})$ & 3 & 35915.78 & 34.24 & 0.0001 & 67.7 \\
\hline $\mathrm{Y} \times \mathrm{T}$ & 6 & 1358.89 & 1.30 & 0.30 & 0 \\
\hline Error $($ trees/T/Y) & 24 & 1048.61 & & & 18.8 \\
\hline \multicolumn{6}{|c|}{ Edible mushroom production } \\
\hline Year $(Y)$ & 2 & 309.32 & 0.70 & 0.5048 & 0.0 \\
\hline Treatments $(\mathrm{T})$ & 3 & 8644.64 & 19.66 & 0.0001 & 67.5 \\
\hline Error (site/trees/T/Y) & 24 & 439.77 & & & 32.5 \\
\hline
\end{tabular}

No significant interactions are not shown 

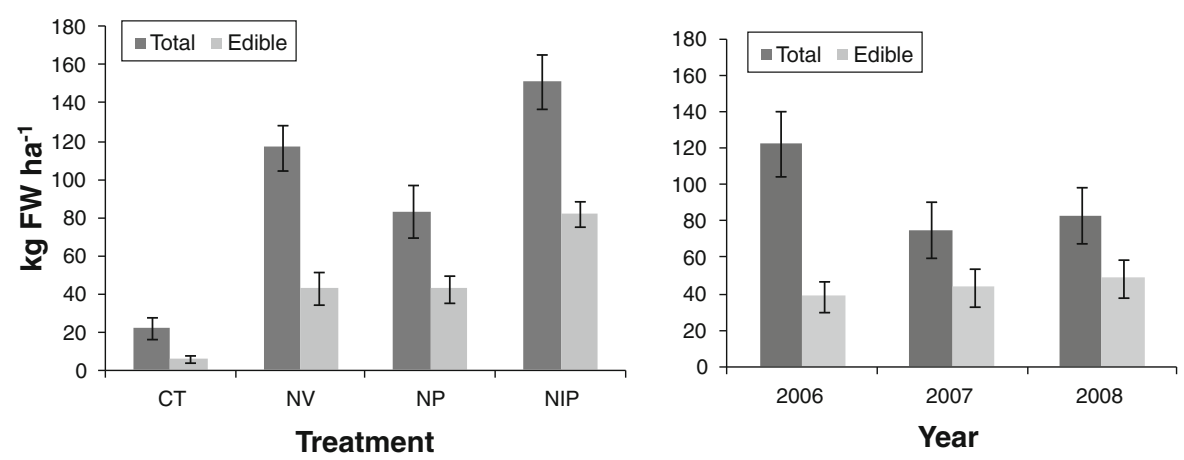

Fig. 4 Total sporocarp and commercial edible mushroom production according to treatments $(n=9)$ and years $(n=12)$. Bars show SE

observed yearly rainfall ranged only from 523 to $719 \mathrm{~mm}$ in the 2006-2008 period, whereas in the 2003-2008 period ranged from 459 to $1335 \mathrm{~mm}$. The annual production of edible-marketed species varied from 38.6 to $48.7 \mathrm{~kg} \mathrm{FW} \mathrm{ha}^{-1}$ (Fig. 4), which is considerably higher than productivity reported for other ecosystems, such as pine forests of Catalonia (Spain), where the production of edible-marketed species ranged from 5.3 to $22.8 \mathrm{~kg} \mathrm{FW} \mathrm{ha}^{-1}$ (Martínez de Aragón et al. 2007).

As observed for total sporocarp production, biomass of edible mushrooms was significantly greater in the NIP (82.0 kg FW ha $\left.{ }^{-1}\right)$ than in the NV and NP treatments (about $43.0 \mathrm{~kg} \mathrm{FW} \mathrm{ha}^{-1}$ ), while that in the CT treatment $\left(6.1 \mathrm{~kg} \mathrm{FW} \mathrm{ha}^{-1}\right)$ was significantly smaller than in the others. The annual fresh weight of the edible-marketed species was 54.2, 51.5, 36.9, and $27.3 \%$ of the total sporocarp production for NIP, NP, $\mathrm{NV}$, and CT treatments, respectively. The highest number of commercial edible species was also collected in the NIP and the lowest in the CT treatment (average 6.0 and 3.0 species, respectively), with intermediate values in the NV and NP treatments (5.7 and 4.7 species, respectively). The greatest proportion of the edible mushroom productivity in the NIP treatment corresponded to Boletus edulis s.l. (average 84\%), while in the NP, NV, and CT treatments the percentage was lower $(67,64$, and $54 \%$, respectively). Although Boletus spp. are usually abundant in forests and agroecosystems of Mediterranean regions and adapted to the intense drought during summer season by the efficiency of water assimilation (Egerton-Warburton et al. 2007; Lilleskov et al. 2009), our results suggest that their productivity can be enhanced by irrigation.
Abundance of Boletus edulis s.l. in the NIP treatment could partially explain the small inter annual variability of edible mushroom productivity. The observed inter annual variability on total sporocarp production, in accordance with other studies (Martínez de Aragón et al. 2007), suggests different responses of the fungal species to weather and environmental soil conditions. With the exception of Lepista nuda, all the other edible-marketed species are ectomycorrhizal, with an extensive fungal network on upper horizons and mineral layers (Dahlberg 2001). They can be able to access deeper water, via hydraulic lift by the host root system, being the water transferred to mycorrhizal symbionts but not to the saprotrophic soil fungi (Querejeta et al. 2003), making the last trophic group more dependent of the soil moisture. As reported by Lilleskov et al. (2009), under dryer conditions, sporocarps obtain a relative high $(25-80 \%)$ portion of their water from deep or hydraulically lifted water, which maintains active the ectomycorrhizal network, even when the soil water potential is very low (Querejeta et al. 2003). Therefore, disturbance in mycelial networks caused by tillage, mainly in the driest spring seasons (in May-June), can decrease significantly the drought resistance of the plant host during the summer period.

\section{Mushroom diversity}

Over the 3-year study period a total of 67 species of fungal sporocarps and 15 taxa identified to genus were collected in the plots, of which one was found to be unique to the CT, five to NV, five to NP and eight to NIP treatments. Only 26 fungal taxa were found in all treatments. The year showed a higher influence 
Table 6 Results of ANOVA tests examining the effect of years and treatments on species richness and sporocarps occurrence

\begin{tabular}{|c|c|c|c|c|c|}
\hline Source of variation & df & Mean square & $F$-value & $P$-value & $\begin{array}{l}\text { Expected } \\
\text { variation }(\%)\end{array}$ \\
\hline \multicolumn{6}{|l|}{ Species richness } \\
\hline Year (Y) & 2 & 831.69 & 52.62 & 0.0001 & 49.9 \\
\hline Treatments $(\mathrm{T})$ & 3 & 458.19 & 28.99 & 0.0001 & 36.1 \\
\hline $\mathrm{Y} \times \mathrm{T}$ & 6 & 25.44 & 1.61 & 0.1878 & 2.1 \\
\hline Error (trees/T/Y) & 24 & 15.81 & & & 11.1 \\
\hline \multicolumn{6}{|c|}{ Sporocarps occurrence } \\
\hline Year $(Y)$ & 2 & 12466.86 & 124.70 & 0.0001 & 56.9 \\
\hline Treatments $(\mathrm{T})$ & 3 & 5109.11 & 51.11 & 0.0001 & 30.7 \\
\hline $\mathrm{Y} \times \mathrm{T}$ & 6 & 476.31 & 4.76 & 0.0025 & 6.9 \\
\hline Error (trees/T/Y) & 24 & 99.97 & & & 5.5 \\
\hline
\end{tabular}

Table 7 Species richness, sporocarps occurrence and Shannon index according to treatments $(n=9)$ and years $(n=12)$

\begin{tabular}{llllllcc}
\hline Treatment & Richness $(S)$ & $\begin{array}{l}\text { Sporocarp } \\
\text { occurrence }\end{array}$ & $\begin{array}{l}\text { Shannon } \\
\text { index } H^{\prime}\end{array}$ & year & Richness $(S)$ & $\begin{array}{l}\text { Sporocarp } \\
\text { occurrence }\end{array}$ & $\begin{array}{l}\text { Shannon } \\
\text { index } H^{\prime}\end{array}$ \\
\hline CT & $11.0 \pm 2.3 \mathrm{a}$ & $20.3 \pm 6.6 \mathrm{a}$ & $2.9 \mathrm{a}$ & 2006 & $28.7 \pm 2.2 \mathrm{a}$ & $86.1 \pm 9.8 \mathrm{a}$ & $3.5 \mathrm{a}$ \\
$\mathrm{NP}$ & $17.9 \pm 3.1 \mathrm{~b}$ & $45.0 \pm 10.1 \mathrm{~b}$ & $3.4 \mathrm{~b}$ & 2007 & $12.1 \pm 1.8 \mathrm{~b}$ & $23.7 \pm 4.3 \mathrm{~b}$ & $3.1 \mathrm{~b}$ \\
$\mathrm{NV}$ & $23.4 \pm 3.1 \mathrm{c}$ & $58.7 \pm 9.3 \mathrm{c}$ & $3.5 \mathrm{~b}$ & 2008 & $19.1 \pm 2.5 \mathrm{c}$ & $40.9 \pm 6.5 \mathrm{c}$ & $3.6 \mathrm{a}$ \\
NIP & $27.4 \pm 2.5 \mathrm{c}$ & $76.9 \pm 13.7 \mathrm{~d}$ & $3.5 \mathrm{~b}$ & & &
\end{tabular}

The values are average plus SE. Different letters in the same column means the existence of significative differences between treatments $(P<0.05)$

both on species richness (49.9\%) and sporocarp occurrence $(56.9 \%)$ (Table 6$)$ than on total sporocarp productivity (13.4\%) (Table 5). As observed for sporocarp productivity, the highest average number of species per plot was observed in 2006 (28.7) while the lowest was in 2007 (12.1) (Table 7). Fungal fructification strongly depends on weather factors (rainfall, temperature and relative air humidity), and some fungal taxa or less vigorous mycelium do not fructify every year (Luoma et al. 2006; Martínez de Aragón et al. 2007).

Species richness was significantly higher in the NIP and NV (27.4 and 23.4, respectively) than in the CT treatments (11.0) (Table 7). The average number of sporocarp occurrences per plot showed a similar pattern, increasing from CT treatment (20.3) to NIP treatment (76.9), with intermediate values on NP (45.0) and NV (58.7) treatments (Table 7).

The year with lowest species richness and sporocarp occurrence (2007) also showed the lowest total diversity, based in the Shannon index (Table 7). Soil management systems significantly affected the diversity of fungal sporocarps. The Shannon diversity index, which takes into account the sporocarp occurrence of a given species as well as number of taxa (O'Dell et al. 2004) was significantly lower in the CT than in the no-tillage treatments NV, NP and NIP (Shannon Diversity $t$-test; $P<0.05$; PAST). The higher diversity of sporocarps in the NIP treatment, as also abovementioned for total productivity, can be explained by the increase in water availability in irrigated plots, given the strong influence of moisture on development of fungal fruiting bodies (Wiklund et al. 1995; O’Dell et al. 1999; Salerni and Perini 2004). The lowest diversity and abundance of fungal sporocarps in the CT treatment are expected since many soil fungi are mainly abundant in the organic layer present on the upper soil surface layers. Vegetation cover and the increase in crop residues in the no-tillage treatments (NV, NP, NIP) may provide a more heterogeneous substrate, with greater amount of organic matter, and may create more favorable microclimatic conditions (Drury et al. 1999) to support fungal metabolic activities and development of sporocarps. In contrast, in the CT treatment, soil organic matter is incorporated into the 
soil and its breakdown is accelerated, as reported in a previous study in the same systems (Raimundo 2003). As most of the fungal sporocarps found in the studied orchard were ectomycorrhizal species, relying on carbohydrates provided from the host tree (Harvey et al. 1997; Dahlberg 2001), their hyphal network is highly susceptible to disturbance (Miller and Lodge 1997), which reduces the density of the fungal mycelium and the $\mathrm{C}$ flow, with deleterious effects on the production and diversity of sporocarps. Furthermore, the regeneration of the fine roots after the tillage is carbon-costly for the tree host and probably implies a reduction on the amount of $\mathrm{C}$ compounds available for fungal populations in the $\mathrm{CT}$ treatment.

Sporocarp data represents an incomplete view of the total soil fungal diversity because, for most of species, the relationship between the sporocarp occurrence and the distribution of the fungal mycelium belowground is unknown (Gardes and Bruns 1996; Horton and Bruns 2001). However, differences in sporocarp abundance between treatments probably reflect different mycelial abundance in the soil, as a result of the soil disturbance and modification of the microclimatic soil conditions. Further long-term research is needed to better understand the impact of disturbance induced by soil management practices on both saprotrophic fungi and mycorrhizal hyphal networks.

Results showed that conservative soil management practices, such as maintenance of a natural vegetation cover, increase the mushroom productivity and diversity, including the edible species. The present results are in accordance with studies (Frey et al. 1999; Alavalapati et al. 2004; Eichhorn et al. 2006; Regato and Salman 2008) reporting that the enrichment of the soil carbon pool by the vegetation cover, improves soil productivity and quality, through reduced erosion, higher water retention, nutrient availability and promoting fungal diversity.
Economic evaluation

The annual input costs for each treatment include the operations related to soil and system management, as reported in Table 8 . The values range from 1,111 to $2,058 € \mathrm{ha}^{-1}$ year $^{-1}$, respectively, for the NV and NIP treatments; values for the latter are mostly associated with irrigation costs.

Taking into account the number of nuts per $\mathrm{kg}$, their price was $1.00 € \mathrm{~kg}^{-1}$ for the CT and NP, and $1.20 € \mathrm{~kg}^{-1}$ for the NV and NIP treatments. Nut gross outputs ranged from a minimum of 2,950 and a maximum of $4,591 € \mathrm{ha}^{-1}$ year $^{-1}$, respectively, for the CT and NV treatments (Table 9). Gross forage outputs reached 908, 746, and $539 € \mathrm{ha}^{-1}$ year $^{-1}$ for the NIP, NP, and NV, respectively, while those of edible mushrooms were $729,330,322$. and $43 € \mathrm{ha}^{-1}$ year- ${ }^{1}$ in the NIP, NP, NV, and CT treatments, respectively. Therefore, total annual gross outputs in the NIP and NV (5,835 and 5,452 € ha ${ }^{-1}$ year $^{-1}$ respectively), almost doubled that estimated for the CT treatment $\left(2,993 € \mathrm{ha}^{-1}\right.$ year $\left.^{-1}\right)$.

The annual net income (Table 9) was higher for the NV and NIP $\left(4,341\right.$ and 3,777 $€$ ha $^{-1}$ year $^{-1}$ respectively) than for the NP and CT treatments $(2,701$ and $1,725 € \mathrm{ha}^{-1}$ year $^{-1}$ respectively). However, the no-tillage system with natural vegetation may be more favourable than the irrigation treatment, based on the higher income and lower environmental costs. In fact, it reduces the threat on the scarce water resources under Mediterranean conditions, which are of utmost importance to assure sustainability of ecosystems dependent on subsoil water resources (Martins et al. 2010). Besides the positive effect on diversity, the notillage system, as reported by Raimundo et al. 2008), may also contribute to enhance soil organic matter status, fulfilling an important role attributed to the agroforestry systems (Schoeneberger 2009).
Table 8 Annual input costs $\left(€ \mathrm{ha}^{-1}\right.$ year $\left.^{-1}\right)$ for each treatment

\begin{tabular}{|c|c|c|c|c|c|c|c|c|}
\hline \multirow[t]{2}{*}{ Treatment } & \multirow{2}{*}{$\begin{array}{l}\text { Tillage } \\
(€)\end{array}$} & \multirow{2}{*}{$\begin{array}{l}\text { Seeding } \\
(€)\end{array}$} & \multirow{2}{*}{$\begin{array}{l}\text { Fertilizers } \\
(€)\end{array}$} & \multirow{2}{*}{$\begin{array}{l}\text { Pruning } \\
(€)\end{array}$} & \multirow{2}{*}{$\begin{array}{l}\text { Irrigation } \\
(€)\end{array}$} & \multicolumn{2}{|l|}{ Harvest } & \multirow[t]{2}{*}{ Total $(€)$} \\
\hline & & & & & & Mushroom $(€)$ & Nuts $(€)$ & \\
\hline $\mathrm{CT}$ & 135 & 0 & 270 & 68 & 0 & 35 & 760 & 1,268 \\
\hline NV & 0 & 0 & 213 & 68 & 0 & 70 & 760 & 1,111 \\
\hline NP & 0 & 39 & 213 & 68 & 0 & 70 & 760 & 1,150 \\
\hline NIP & 0 & 39 & 213 & 68 & 908 & 70 & 760 & 2,058 \\
\hline
\end{tabular}


Table 9 Average values of annual gross output $\left(€ \mathrm{ha}^{-1}\right.$ year $\left.^{-1}\right)$, annual input costs and annual net income for the study management systems

\begin{tabular}{llrllll}
\hline Treatments & \multicolumn{2}{l}{ Gross outputs $\left(€ \mathrm{ha}^{-1}\right.$ year $\left.^{-1}\right)$} & & $\begin{array}{l}\text { Input costs } \\
\left(€ \mathrm{ha}^{-1} \mathrm{year}^{-1}\right)\end{array}$ & $\begin{array}{l}\text { Net income } \\
\left(€ \text { ha }^{-1} \text { year }^{-1}\right)\end{array}$ \\
\cline { 2 - 5 } & Nuts & Forage & Mushrooms & Total & & \\
\hline CT & $2.950(€)$ & $0(€)$ & $43(€)$ & $2,993(€)$ & $1,268(€)$ & $1,725(€)$ \\
NV & $4.591(€)$ & $539(€)$ & $322(€)$ & $5,452(€)$ & $1,111(€)$ & $4,341(€)$ \\
NP & $2.775(€)$ & $746(€)$ & $330(€)$ & $3,851(€)$ & $1,150(€)$ & $2,701(€)$ \\
NIP & $4.198(€)$ & $908(€)$ & $729(€)$ & $5,835(€)$ & $2,058(€)$ & $3,777(€)$ \\
\hline
\end{tabular}

\section{Conclusions}

Wide differences on fruit production and size, forage and mushroom production and diversity, were observed for the study management systems. No-tillage systems with natural vegetation (NV) or irrigated seeded pastures (NIP) enhance fruit production and fruit quality parameters, but the latter shows higher forage production. Conservative soil management practices (NV, NP, and NIP), also significantly increase productivity of mushrooms in chestnut orchards, including ediblemarketed species (with high amount of Boletus edulis s.l.), which is considerably higher than that reported for other ecosystems. Such systems may contribute for a sustainable management of the wild edible mushrooms increasingly collected and commercialized. Weather conditions strongly affect the system productivity, fungal species richness and sporocarp occurrence increasing the production with the amount of rainfall. The no-tillage system treatment (with spontaneous herbaceous vegetation) seems to be the most favourable management system to assure productivity and sustainability of chestnut plantations, as it lead to the highest annual net income and may contribute to reconcile productive, environmental, economic and social issues. The multifunctional management of chestnut plantations may create a sustainable land-use system, promoting economic diversification, biodiversity, and environmental quality.

Acknowledgments The authors thank to the European project MANCHEST (Contract QLK5-2001-00029), PROCAST project (No. 391 of AGRO program) and CITAB, which supported this study. José Carlos Rego and Jani Costa Pires are acknowledged for assistance on measurements and samplings. Prof Ana Carla Madeira is acknowledged for English style improvement.

\section{References}

Abreu CG, Coutinho JF, Cardoso AO, Campos JA (1993) Suppressive soils and chestnut ink disease. In: Antognozzi
E (ed) Proceedings of the International Congress on Chestnut, Spoleto, Italy, pp 533-536

Alavalapati JRR, Shrestha RK, Stainback GA, Matta JR (2004) Agroforestry development: An environmental economic perspective. Agroforest Syst 61:299-310

Arnolds E (1995) Conservation and management of natural populations of edible fungi. Can J Bot 73(1):S987-S998

Beare MH, Hu S, Coleman DC, Hendrix PF (1997) Influences of mycelial fungi on soil aggregation and organic matter storage in conventional and no-tillage soils. Appl Soil Ecol 5(3):211-219

Boa E (2004) Wild edible fungi. A global overview of their use and importance to people. Non-wood forest products, Series $n^{\circ} 17$, FAO, Rome

Botu M, Achim GH, Turcu E (1999) Evaluation of some chestnut selections from the population formed into the ecological conditions from Northeast Oltenia. Proceedings of the second International Symposium on Chestnut. Acta Hortic 494:77-83

Branzanti MB, Rocca E, Pisi A (1999) Effect of ectomycorrhizal fungi on chestnut ink disease. Mycorrhiza 9:103-109

Celette F, Wery J, Chantelot E, Celette J, Gary C (2005) Belowground interactions in a vine (Vitis vinifera $\mathrm{L}$.)-tall fescue (Festuca arundinacea Shreb.) intercropping system: water relations and growth. Plant Soil 276:205-217

Dahlberg A (2001) Community ecology of ectomycorrhizal fungi: an advancing interdisciplinary field. New Phytol 150:555-562

Doran JW, Zeiss MR (2000) Soil health and sustainability: managing the biotic component of soil quality. Appl Soil Ecology 15:3-11

Drury CF, Tan CS, Welacky TW, Oloya TO, Hamill AS, Weaver SE (1999) Red clover and tillage influence on soil temperature, water content, and corn emergence. Agron J 91:101-108

Dupraz C, Simorte V, Dauzat M, Bertoni G, Bernadac A, Masson P (1998) Growth and nitrogen status of young walnuts as affected by intercropped legumes in a Mediterranean climate. Agroforest Syst 43:71-80

Egerton-Warburton LM, Querejeta JI, Allen MF (2007) Common mycorrhizal networks provide a potential pathway for the transfer of hydraulically lifted water between plants. J Exp Bot 58:1473-1483

Eichhorn MP, Paris P, Herzog F, Incoll LD, Liagre F, Mantzanas K, Mayus M, Moreno G, Papanastasis VP, Pilbeam DJ, Pisanelli A, Dupraz C (2006) Silvoarable systems in Europe-past, present and future prospects. Agroforest Syst 67:29-50

FAO (2006) World reference base for soil resources, 2nd ed. World Soil Resources Reports No. 103. FAO, Rome 
Ferreres E, Evans RG (2006) Irrigation of fruit trees and vines: an introduction. Irrig Sci 24:55-57

Frey SD, Elliot ET, Paustian K (1999) Bacterial and fungal abundance and biomass in conventional and no-tillage agroecosystems along two climatic gradients. Soil Biol Biochem 31:573-585

Garbaye J (2000) The role of ectomycorrhizal symbiosis in the resistance of forests to water stress. Outlook Agric 29(1):63-69

Gardes M, Bruns TD (1996) Community structure of ectomycorrhizal fungi in a Pinus muricata forest: above- and below-ground views. Can J Bot 74:1572-1583

Glenn DM, Welker WV (1989) Cultural practices for enhanced growth of young peach trees. Am J Altern Agr 4:8-11

Goldhamer DA, Viveros M, Salinas M (2006) Regulated défice irrigation in almonds: effects of variations in applied water and stress timing on yield and yield components. Irrig Sci 24:101-114

Hammer $\emptyset$, Harper DAT, Ryan PD (2001) PAST: Palaentological Satistics software package for education and data analysis. Palaeontol Electro4(1):9

Hargreaves GH (1975) Moisture availability and crop production. Trans Am Soc Agric Eng 18(5):980-984

Harvey AE, Page-Dumroese DS, Jurgensen MF, Graham RT, Tonn JR (1997) Site preparation alters soil distribution of roots and ectomycorrhizae on outplanted western white pine and Douglas-fir. Plant Soil 188:107-117

Hernández AJ, Lacasta C, Pastor J (2005) Effects of different management practices on soil conservation and soil water in a rainfed olive orchard. Agric Water Manage 77: 232-248. doi:10.1016/j.agwat.2004.09.030

Hogue EJ, Neilsen GH (1987) Orchard floor vegetation management. Hortic Review 9:377-430

Horton TR, Bruns TD (2001) The molecular revolution in ectomycorrhizal ecology: peeking into the black-box. Mol Ecol 10(8):1855-1871

INE (2005) Estatísticas Agrícolas 2004 Instituto Nacional de Estatística, Lisboa, Portugal

INMG (1991) Normais Climatológicas da Região de Trásos-Montes e Alto Douro e Beira Interior, Correspondentes a 1951-1980 O Clima de Portugal. Fascículo XIII, Vol. 3-3 ${ }^{a}$ Região. Instituto Nacional de Meteorologia e Geografia, Lisboa

Jose S, Gillespie AR, Pallardy SG (2004) Interspecific interactions in temperate agroforestry. Agroforest Syst 61: 237-255

Krebs CJ (1994) Ecology: The experimental analysis of distribution and abundance, 4th edition. Harper Collins Publishers, New York

Lilleskov EA, Bruns TD, Dawson TE, Camacho FJ (2009) Water sources and controls on water-loss rates of epigeous ectomycorrhizal fungal sporocarps during summer drought. New Phytol 182:483-494

Lipecki J, Berbeć S (1997) Soil management in perennial crops: stands and hop gardens. Soil Till Res 43:169-184

Lund HG (eds) (1998) IUFRO Guidelines for designing multipurpose resource inventories. In: IUFRO World Service vol. 8. Vienna, Austria, p 216

Luoma DL, Eberhart JL, Molina R, Amaranthus MP (2004) Response of ectomycorrhizal fungus sporocarp production to varying levels and patterns of green-tree retention. For Ecol Manag 202:337-354

Luoma DL, Eberhart JL, Abbott R, Moore A, Amaranthus MP, Pilz D (2006) Effects of mushroom harvest technique on subsequent American matsutake production. For Ecol Manag 236:65-75

Marcelino V, Torres N, Portela E, Martins A (2000) Soil physical properties and the occurrence of chestnut ink disease: a micromorphological study. Ecol Mediterranea 26:129-135

Martínez de Aragón J, Bonet JA, Fischer CR, Colinas C (2007) Productivity of ectomycorrhizal and selected edible saprotrophic fungi in pine forests of the pré-Pyrenees mountains, Spain: predictive equations for forest management of mycological resources. For Ecol Manag 252:239-256

Martín-Pinto P, Vaquerizo H, Peñalver F, Olaizola J, Oria-deRueda JA (2006) Early effects of a wildfire on the diversity and production of fungal communities in Mediterranean vegetation types dominated by Cistus ladanifer and Pinus pinaster in Spain. For Ecol Manag 225:296-305

Martins LM, Abreu CG (1997) Solos supressivos: um meio de luta cultural contra a doença da tinta do castanheiro. Rev Biol 16:113-117

Martins LM, Oliveira MT, Abreu CG (1999) Soils and climatic characteristics of chestnut stands that differ on the presence of ink disease. Acta Hortic 494:447-449

Martins A, Linhares I, Raimundo F, Borges O, Coutinho JP, Gomes-Laranjo J and Sousa V (2005) The importance of deep soil layers to supply water to agroforestry system: A case study of a mature chestnut orchard in Northern Portugal. In: Abreu CG, Rosa E, Monteiro AA (eds) Proceedings of the third International Chestnut Congress. Acta Hortic 693:663-670

Martins A, Raimundo F, Borges O, Linhares I, Sousa V, Coutinho JP, Gomes-Laranjo J, Madeira M (2010) Effects of soil management practices and irrigation on plant water relations and productivity of chestnut stands under Mediterranean conditions. Plant Soil 327:57-70. doi:10.1007/ s11104-009-0031-0

Miller RM, Lodge DJ (1997) Fungal responses to disturbance: agriculture and forestry. In: Wicklow DT, Södeström B (eds) The Mycota IV. Environmental and microbial relationships. Springer, Heidelberg, pp 65-84

Moreira N (2007) Alternativas pratenses e forrageiras para a Terra Quente Transmontana. Pastagens e Forragens 28: 199-207

Moreira N, Trindade H (1992) Implantação de pastagens de sequeiro no planalto de Miranda - Terra Fria Transmontana. Pastagens e Forragens 13:41-49

Moreno G (2008) Response of understorey forage to multiple tree effects in Iberian dehesas. Agric Ecosyst Environ 123:239-244

Morlat R, Jacquet A (2003) Grapevine root system and soil characteristics in a vineyard maintained long-term with or without interrow sward. Am J Enol Vitic 54:1-7

Nortcliff S (2002) Standardisation of soil quality attributes. Agric Ecosyst Environ 88:161-168

O’Dell TE, Ammirati JF, Schreiner EG (1999) Species richness and abundance of ectomycorrhizal basidiomycete 
sporocarps on a moisture gradient in the Tsuga heterophylla zone. Can J Bot 77(12):1699-1711

O’Dell TE, Lodge DJ, Mueller GM (2004) Approaches to sampling macrofungi. In: Biodiversity of fungi: inventory and monitoring methods. Elsevier Academic Press, Amsterdam, pp 163-168

Pereira E, Madeira M, Martins A, Monteiro ML (2002) Aspectos genéricos da influência do freixo nos lameiros do Nordeste Transmontano (General aspects of ash-tree in natural pastures of northeastern Portugal). Revista de Ciências Agrárias XXV (1-2):146-157

Pérez-Pastor A, Domingo R, Torrecillas A, Ruiz-Sánchez Ma C (2009) Response of apricot trees to deficit irrigation strategies. Irrig Sci 27:231-242

Portela E, Aranha J, Martins A, Pires AL (1999) Soil factors, farmer's practices and chestnut ink disease: some interactions. Acta Hortic 494:433-441

Querejeta JI, Egerton WLM, Allen MF (2003) Direct nocturnal water transfer from oaks to their mycorrhizal symbionts during severe soil drying. Oecologia 134:55-64

Raimundo F (2003) Sistemas de mobilização do solo em soutos: Influência na produtividade de castanha e nas características físicas e químicas do solo. $\mathrm{PhD}$ dissertation. Universidade de Trás-os-Montes e Alto Douro, Vila Real, Portugal

Raimundo F, Martins A, Madeira M (2008) Decomposition of chestnut litterfall and eight-year soil chemical changes under a no-tillage management system in Northern Portugal. Ann For Sci 65 (4): 408-419. doi: 10.1051/forest: 2008021

Ramos ME, Benítez E, García PA, Robles AB (2010) Cover crops under different managements vs frequent tillage in almond orchards in semiarid conditions: effects on soil quality. Appl Soil Ecol 44:6-14. doi:10.1016/j.apsoil.2009. 08.005

Regato P, Salman R (2008) Mediterranean mountains in a changing world: guidelines for developing action plans. IUCN Centre for Mediterranean Cooperation, Malaga, Spain

Rozados-Lorenzo MJ, González-Hernández MP, Silva-Pando FJ (2007) Pasture production under different tree species and densities in an Atlantic silvopastoral system. Agroforest Syst 70:53-62

Salerni E, Perini C (2004) Experimental study for increasing productivity of Boletus edulis s.1. in Italy. For Ecol Manag 201:161-170

Schloter M, Dilly O, Munch JC (2003) Indicators for evaluating soil quality. Agric Ecosyst Environ 98:255-262

Schoeneberger MM (2009) Agroforestry: working trees for sequestering carbon on agricultural lands. Agroforest Syst 75:27-37

Smith SE, Read DJ (1997) Mycorrhizal symbiosis. Academic Press, London

Termorshuizen AE, Schaffers A (1991) The decline of carpophores of ectomycorrhizal fungi in stands of Pinus sylvestris L. in The Netherlands: possible causes. Nova Hedwigia 53(3-4):267-289

Vandmermeer J (1989) The ecology of intercropping. Cambridge University Press, Cambridge

Wiklund K, Nilsson LO, Jacobsson S (1995) Effect of irrigation, fertilization, and artificial drought on basidioma production in a Norway spruce stand. Can J Bot 73: 200-208 